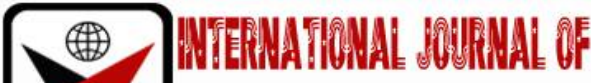

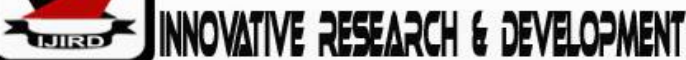

ISSN 2278 - 0211 (Online)

\section{The Impacts of Violent Conflicts, Injustice and Weak Institutions on the Effective Delivery of the SDGs and Agenda 2030}

\begin{tabular}{c} 
Dr. Noel Ihebuzor \\
Development Consultant, Department of Evidentis Development Associates, \\
Abuja, Nigeria \\
Anthony Wakwe Lawrence \\
Chairman, Department of Management, \\
Community Inter-Relations and Conciliation Initiative (CIRCI), Nigeria \\
Dr. Miebaka Tamunomiebi \\
Associate Professor, Department of Management, \\
Rivers State University, Port Harcourt, Rivers State, Nigeria \\
Damiete Onyema Lawrence \\
Ph.D. Student, Department of Management \\
Rivers State University, Port Harcourt, Rivers State, Nigeria \\
Dr. Barasua A. Lawrence \\
Administrator, Department of Enitonna High School, \\
Rivers State Universal Basic Education Board, Port Harcourt. Rivers State, Nigeria \\
\hline
\end{tabular}

\section{Abstract:}

SDG16 (Promote just, peaceful, and inclusive societies) is a critical sustainable development goal without which all the other 16 sustainable development goals become inherently unsustainable. Justice, peace and inclusiveness are key ingredients for attaining the aspirations expressed in Agenda 2030 and its visions of a safe, prosperous and peaceful world. We used the problem tree analyses to $x$-ray the causes and consequences of conflicts, injustice and weak institutions, which are the negative outcomes of a not well implemented SDG16 and as a way to also underscore the criticality of issues under the purview of this SDG. The three problem tree analyses revealed that the causes/consequences of aggravated conflicts, injustice and weak institutions are often similar and interwoven. These three legs of peaceful coexistence, justice for all and strong enabling institutions are critical to ensure and enhance sustainable development at all levels. Any society with prevalent injustice cannot enjoy peace and societies need strong institutions to enforce justice. As can be deduced, strong institutions in active democracies can tame leadership impunity, allow for rule of law to thrive and assist in the controlling of the occurrence of crimes.

Keywords: Peaceful-coexistence, capacity-building, strong-institutions, violent-conflicts, SDG (Sustainable Development Goal)

\section{Introduction}

SDG16 (Promote just, peaceful, and inclusive societies) is a critical sustainable development goal without which all the other 16 sustainable development goals become inherently unsustainable to a great extent in the long run. Justice, peace and inclusiveness are key ingredients for attaining the aspirations expressed in Agenda 2030 and its visions of a safe, prosperous world characterised by global peace, amity, equity and people centred development that is both sustainable and environment friendly. For example, a world without wars and conflicts will be more conducive towards rapid and inclusive sustainable development because of the economic, social and psychological externalities of peace. The value attached to global peace and amity is best captured in the inscription 'they shall beat their swords into plough-shares, and their spears into pruning hooks; nation shall not lift up sword against nation, neither shall they learn war any more' taken from the Christian scriptures (Isaiah 2:4) and which adorns a building on UN Plaza right in front of the United Nations Headquarters in New York. The message is clear - wars destroy, peace builds up. Similar claims can be made about the relationship between justice and development on the one hand and between inclusion and development on the other (Bali-Swain and Yang-Wallentin, 2020). Whereas injustice and other forms of lack of fairness lead ultimately to tensions and to conflicts at the societal, national and international levels, exclusion and all other forms of discriminations weaken social cohesion and social capital whilst widening and exacerbating social cleavages in society. Peace, justice and 
inclusiveness in all their forms and manifestations - personal, social, environmental and economic - are thus very vital for sustainable development at the global and national levels(Gupta and Vegelin, 2015). The absence of peace, justice and inclusiveness also spell disaster for the pursuit development for as the UN Sustainable Development goal report 2019 had observed with regard to SDG16 'Conflict, insecurity, weak institutions and limited access to justice remain a great threat to sustainable development. Equally, it has been observed at the Conference on SDG 16 that SDG 16 - 'promoting peaceful and inclusive societies for sustainable development, providing access to justice for all, and building effective, accountable and inclusive institutions at all levels' - that this goal is both an outcome and an enabler of sustainable development as it is interlinked with other SDGs. The conference organisers noted that 'Without peace, justice and inclusion, achieving goals such as ending poverty, ensuring education, promoting economic growth can be difficult or impossible. At the same time, various SDGs can help or hinder the achievement of SDG 16, for instance climate change can act as a threat multiplier, aggravating additional social, environmental and political stressors, conditions that could possibly lead to violence (UNDESA and IDLO, 2019, p1).

Peaceful, just and inclusive societies are built on principles of truth, fairness and respect for human dignity. Bedrocks for peaceful, harmonious, and progressive human societies are leadership, exhibition of equity, justice, meritocracy, no discrimination, transparency/accountability, and inclusiveness. Building such societies also require having the political will to strengthen all institutions to perform their statutory duties. Some of such institutions include the law enforcement outfits, election management umpires, legislature, the press, universities, among many.

These three legs of peaceful coexistence, justice for all and strong enabling institutions are critical to ensure and enhance sustainable development at all levels. Any society with prevalent injustice cannot enjoy peace and societies need strong institutions to enforce justice. As can be deduced, strong institutions in active democracies can tame leadership impunity, allow for rule of law to thrive and assist in the controlling of the occurrence of crimes.

\section{Literature Review}

Our literature review examined issues on peace, justice, and inclusion. Recent riots in the United States of America have shown that weaknesses in institutions do lead to conflicts. Issues of non-inclusiveness have resulted in several conflicts in many nations. The SDGs insists on inclusive development and the mantra of the new SDGs is 'Leave no one behind'. The Gini index', a statistical index which gives a measure of the dispersal in income across different percentile in society is particularly apposite here as it reflects how inclusive a society is in its structuring. A high Gini index indicates a high measure of income inequality and by implication a high measure of exclusion, something which bodes poorly for feelings of oneness and societal cohesion. It has been observed that the better a society's performance on this index(that is by scoring low on the Gini index and showing minimal income disparity, and by implication, stronger integration and inclusion), the more it is likely that the society will show signs of low tension and divisiveness. In such societies, the pursuit of sustainable development would be facilitated as sustainable development is built on a tripod of people, inclusive prosperity/progress, and respect for the planet (environment).

\subsection{Peace}

According to Etymonline (2017), the word peace is derived from the Latin word 'pacem' and 'pax', which means peace, reconciliation, permission compact, treaty of peace, tranquillity, the absence of war. The theory of peace is as old as war; peace is perceived as the absence of violence and a fleeting fragile state; with war seen as the natural state (Richmond, 2014). This concept should be challenged since in recent times the probability of a war outbreak is low. Peace can be sought locally, internally, or trans-nationally (covering both domestic and international areas); which can be regarded as public or private. Furthermore, the Institute for Economics and Peace (IEP) explained that, peace can manifest in two forms which are: Negative peace and Positive peace (IEP, 2016). They further explained that Negative peace is nothing but the fear for violence. While, Positive peace comprises of the attitude and approach used in building and sustaining a peaceful society, which can be evident in good governance, beneficial goods, and services.

Various scholars have defined peace from a number of perspectives. Einstein (1968) defined it not only as the absence of war or conflict, but the existence of justice, law and order in the government. Similarly, Reardon (1988) opined that it is the absence of physical, social, structural, and psychological violence, which results from the combination of trust, justice and compassion (Trostles, 1992). Peace can be considered as that condition of a non-violent atmosphere which promotes individual and collective functionality.

According to Global Peace Index (GPI, 2017), peace can be measured by Societal Safety and Security and the Current Domestic and International Conflict.

- Societal Safety and Security: The term societal safety first gained currency as a concept in 1997 and may be said to express 'the spirit of the age' (Olsen et al, 2007). Societal safety can be considered as ability to maintain critical social functions, to protect the life and health of the citizens and to meet the citizens' basic requirements in a variety of stress situations' (Norwegian Parliamentary White Paper No. 17, 2001-2002). This concept was developed as a response to the emergence of risks and vulnerabilities after the Cold War (Olsen et al, 2007). This Peace dimension can be measured in the ability of a society to defend itself or wage war (Quarantelli, 2000). Societies should pay great attention to both civil and military measures in protecting public functions in order to develop capacity to advocate peace and prepare for war and post-war.

- Domestic and International Conflict: Lawrence and Lawrence (2019) argued that peace can be measured by the absence of domestic and international conflict in a society. On the basis of a premise that conflicts arise from unacceptable difference between reality and what is desired - in needs, values, and expectations within an individual or a group and with others, they then posit that the frequent occurrences of conflict within a society or 
between different societies can give insights into the substantiality of peace in that society by revealing how members of that society are able to handle their disparities and deploy conflict resolution procedures necessary for the promotion of peaceful coexistence. Peace exists when the enabling institutions, values and personal and collective skills exist in any society - the higher their presence the greater the amount and solidity of peace.

\subsection{Justice}

Justice is the most significant discuss of a state, and society. It is the basis of orderly human living. The application of justice differ in every culture, the theory of Justice considers that the standard people receive is that which they deserve (Rawl, 1999); which demands the regulation of selfish actions with an understanding of what then constitutes 'deserving' being impacted upon by various disciplines with many perspectives, which consists of the concept of moral based on rationality, equity and etc. Justice is a system in which people are joined in a close association, ensuring fair order of relationships, as well as harmonizing individual interests with societal interest. The recognition of the role that justice plays in ensuring peace and development is best brought out by the fact that the global community has instituted a World Justice Project (Long and Ponce, 2019). The project painfully reminds us that millions of people in this world exist with unmet justice needs, cannot get justice for everyday problems and are excluded from the opportunity that the law provides. The result is exclusion, which leads to weakness in social capital and cohesion and eventually to conflicts. Long and Ponce (2019) stated some reasons for these unmet justice needs to include: distance from courts, legal fees, social class and other drivers of exclusion.

Some theorists believe justice is a divine command issued from God. While theorist like John Locke advocated it to be part of Natural Law which is derived from any action or choice. Furthermore, Social thinkers considered it to be derived from a mutual agreement of everyone concerned (Ornstein, 2017). However, John Stuart Mill, a utilitarian thinker opined that justice was based on the best outcomes for the greatest number of people (Mill, 1991); which varies from the Egalitarians who perceive justice to exist only within the coordinates of equality (Hayek, 1976).

In this paper we conceptualized justice as being made up of four factors: social, economic, political, and legal.

Social Justice: This dimension focuses on 'equal rights' and the just relationship between individuals and their society, with regulation on the distribution of privileges, opportunities and wealth amongst individuals (Wiedeman, 2002). Also, Ornstein (2017) associated social justice with social mobility; the comfort with which individuals and families move between social echelons, advocating all people are equal in terms of status, value or right. Rubinstein (1988) explained that, the root of this concept of justice is that each person should receive rewards that are proportional to their contributions.

Economic Justice: This type of justice demands that all citizens should have adequate opportunities to earn their livelihood and get fair wages that can enable them to satisfytheir basic needs and continuous development (Rocha, 2009). Since, economic system is an integral part of the social system, through economic rights and opportunities, economic justice will continuously be part of social justice. This justice ensures that no person or group remain in positions to exploit others or get exploited, implying, fair and equitable distribution of wealth and resources among citizens, which in turn reduces the gap between the rich and the poor (Kapstein, 2006).

Political Justice: This refers to the equality of all persons in the society to take on political positions regardless of their colour, sex and etc. (Eriksen, 2016). Eriksen (2016) also explained that, it was placed to reduce discrimination and give equal opportunity for country administration to all; every citizen should have an equal right to vote and to contest an election.

Legal Justice: It consist of two things; that all men are equal before law According to (Johnson, 2016), and that law is equally applicable to all; providing legal security to all, it does not discriminate between the rich or poor, which implies the rule of law and not the rule of any person. Legal justice has two parts namely, the formulation of just laws and then to do justice according to the stated laws. According to Bignami and Zaring (2016) Laws are not made without the consent of its society, they are made based on public opinion and needs, and the will of the rulers is not imposed upon the rule. Social values, morality, conventions, the idea of just and unjust are always kept in perspective during law making, else the probability of acceptance or abiding is farfetched, inferring challenges with law enforcement.

Positive developments in Justice in all its four forms create the enabling conditions for Peace and stability. These conditions, in turn, further create the enabling conditions for the emergence of strong institutions which are not only accountable but are also equity driven. Such institutions provide for rule of law, create conditions for transparent fairness and thus lead to economic growth and poverty reduction. Justice is real only when it exists in the above stated dimensions. Without Social and Economic Justice there can be no real Political and Legal justice and vice versa. The absence or denial of justice eventually leads to societal chaos (the absence of peace).

\subsection{The Consequences of Lack of Peace}

Lawrence (2018) graphically demonstrated the inverse relationships between Development and violence/war. See figure 1 below: 


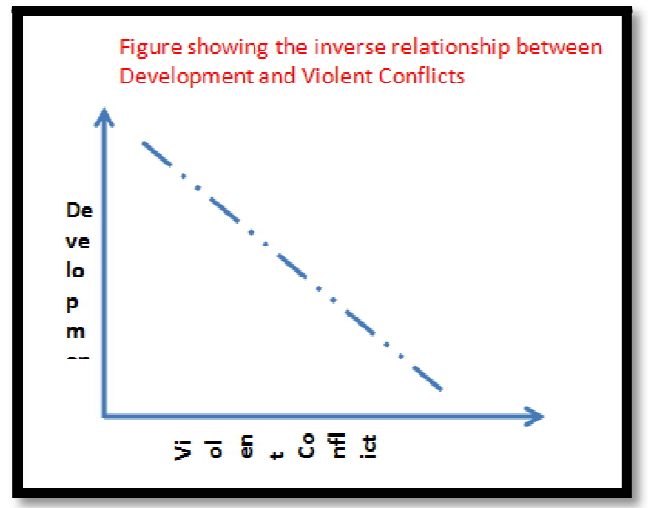

Figure 1

Source: Lawrence (2018) Some Governance and Peaceful Coexistence

Issues for Sustainable Advancement: A Nigerian Perspective, P 99

The above figure explains the relationship between development, and lack of peace. It equally explains the relationship between development and all forms of violence. Lawrence (2018) pp 97-101 'Violence can be referred to as the use of physical, psychological, or verbal force against self or others. It can take many forms, ranging from mere hitting between people causing bodily harm to war and genocide with huge numbers of fatalities. Violence can also be verbal, psychological, emotional, and spiritual as well as physical. Structural violence includes pervasive poverty, exclusion, hunger, exploitation, intimidation, oppression, fear, and the like. Even if structural violence is not physical, it can easily degenerate into physical violence. War on the other hand is a state of prolonged violence.

Where there is lack of peace, oppression, victimization, exploitation etc, the victims may not be happy and in such a situation violent confrontation is always a possibility and lack of peace culminating in violence or war cannot coexist with development. The graphical presentation above (Figure 1) amply explains the inverse relationship between peace and development.

\section{Methodology}

The use of problem tree analyses was utilized to assess the causes, effects and the consequences of absence of the following: peace, justice and strong institutions, which are manifesting as violent conflicts/wars, injustice and weak institutions. These analyses were done with the aim of providing a stark visual display of some of the drivers and consequences of these three negative tendencies in societies that SDG16 seeks to address and eliminate.

The problem tree can be utilized during the initial stage of evaluation when faced with a complex and vaguely defined problem (Veselý,2008; p68-70). The problem tree is a tool for identifying, prioritizing, and visualizing problems. It represents a scheme of problem causes (factors) and effects (consequences) and like every tree, the problem tree has its 'stem', 'roots', and 'branches'. Its stem stands for the core problem, its roots are the causes and its branches form the problem's effects.

\section{Findings/Discussion}

\subsection{Problem Tree Analysis}

\subsubsection{Problem Tree Analysis for Major Conflicts}

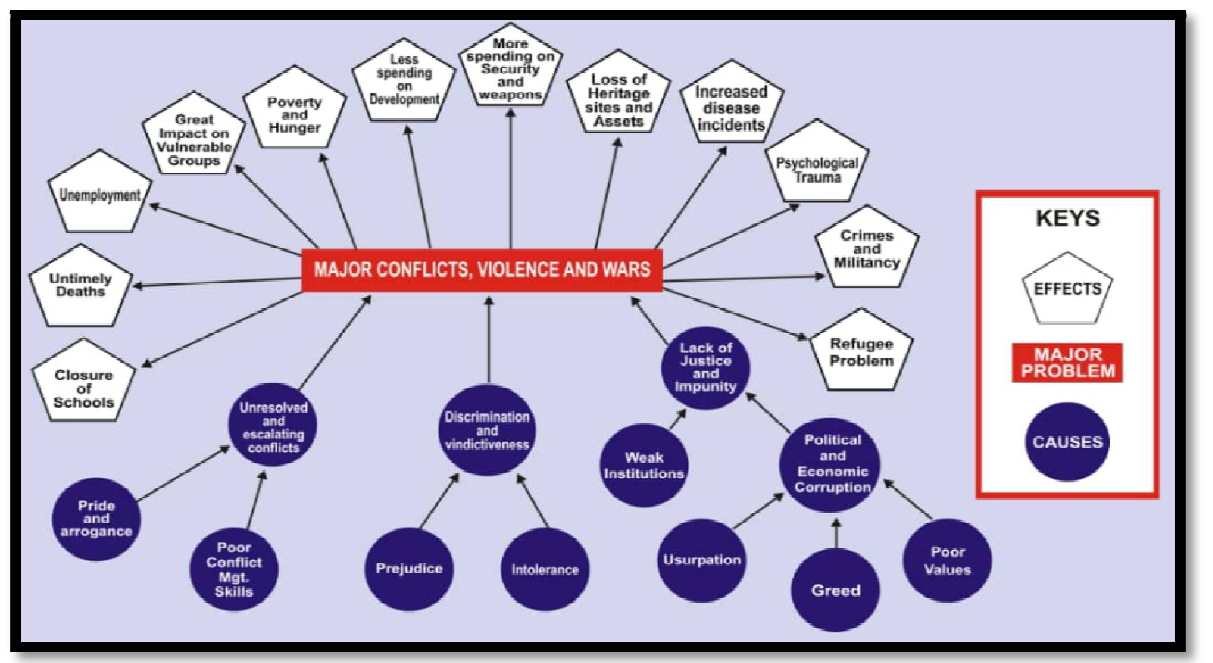

Figure 2: Problem Tree of Causes and Effects of Violent Conflicts

Source: Conceptualised by Authors (2020) 
Peace is a major trust of SDG16. The absence of peace is conflict and the persistence of conflicts globally and within countries suggests that SDG16 is facing challenges with the attainment of the targets for achieving peace.The problem tree analysis was useful in that it revealed in a visually comprehensible manner the underlying and structural causes of conflicts and violence. Unearthing these causes amounts to major step in finding solutions to end such conflicts whose final consequences are the inhibition of sustainable development and the diversion of resources away from constructive purposes to the services of destructive engagements. The diagram shows that the major causes of violent conflicts and wars are unresolved and escalating conflicts, discrimination and vindictiveness by leadership, and lack of justice and endemic impunity. Each of these has underlying causes too. Unresolved and escalating conflicts are mainly caused by pride and arrogance on the part of the contenders and lack of conflict management skills. Discrimination and vindictiveness on the other hand are caused mainly by prejudice and intolerance, among others. Lack of justice and endemic impunity are caused by numerous factors including weak institutions and political/economic corruptions. Many believe that a major source of problem is corruption and we therefore made further drill down to identify usurpation tendencies by people who are relatively powerful, people who are greedy and societies suffering degenerating value system as major factors. Government diverting the funds for development to providing security and purchase of weapons, suspension of schools and other learning institutions, increasing psychological trauma among the people, greater exposure impacts on the vulnerable component of the society (women, youths, children and the poor), increasing incidents of crimes and militancy, and increasing cases of refugees are among the consequences.

Violent conflicts and wars do not only cause deaths, other casualties include: loss of historic and cultural heritage sites, destruction of critical developmental amenities/infrastructure, homes etc.Often attacking parties target key assets for revenue generation or assets that the people have political or religious attachments to, for the purpose of destroying or annexing them. Some of these developmental entities collectively owned or houses etc. owned by individuals that are destroyed overnight took the people several decades to put together.

It is worth recalling in consideration of the destructive powers of conflicts, the aspirations of Sustainable Development Goal 16 may be threatened, which are to 'Promote peaceful and inclusive societies for sustainable development, provide access to justice for all and build effective, accountable, and inclusive institutions at all levels' if not well managed. Clearly, the problem tree analysis has shown that conflicts and violence inhibit the pursuit and attainment of such aspirations. Among the issues militating against rapid and sustainable development in every society is the perpetual and endemic nature of conflicts especially those culminating in violence and wars.

Similarly, problem tree analyses were applied to examining the causes and consequences of Injustice and weak institutions.

\subsubsection{Problem Tree Analysis for Injustice}

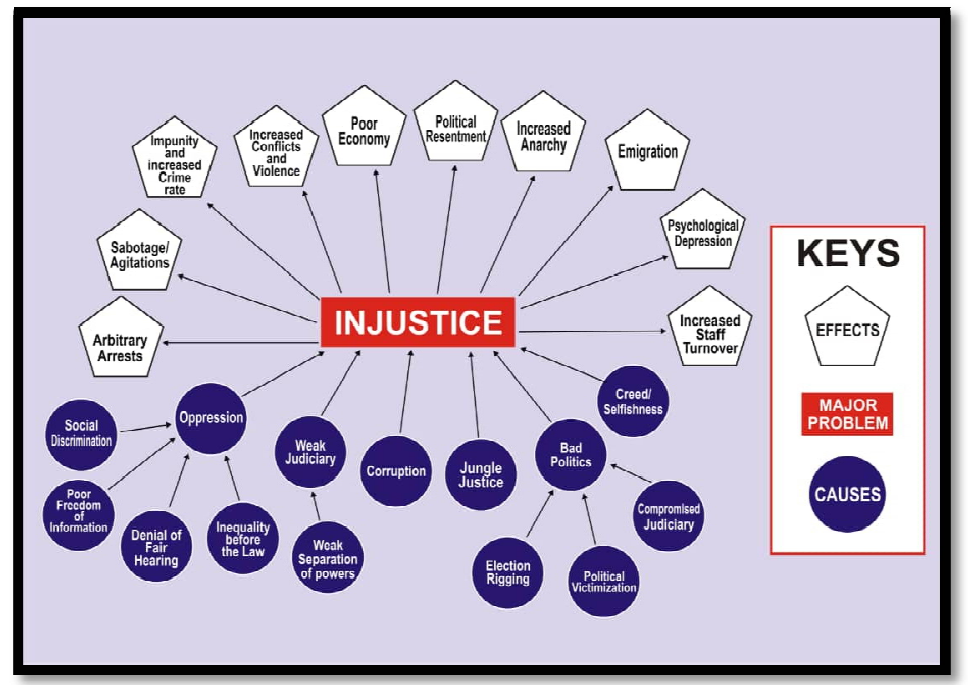

Figure 3: Showing the Problem Tree Analysis of Injustice Source: Conceptualised by Authors (2020)

Some of the key causes of injustice are oppressive tendencies by leaders, weakened judiciary, corruption, jungle justice, bad politics and actions of greedy and selfish people. Oppression and vindictiveness themselves are caused by social discrimination/prejudice, poor/lack of freedom to acquire information, denial of fair hearing, and inequality before the law among others. Weak judiciary is enforced by the fact that there is weak separation of powers. Three of the major causes why there is bad politics are: insensitivity by politicians who do anything (wise or unwise, considerate or inconsiderate, legal or illegal) without any remorse because they hope to rig their way back to power. The dearth of accountability spells death for justice and social stability. Furthermore, weak institution and absence of structures that promote justice create conditions where opposition party members can be easily victimised, a regular occurrence in many nations where the judiciary has been compromised and reduced to carrying out the dictates of the executive arm of government. 
The entire short comings above have several deleterious consequences among which are arbitrary arrest of innocent citizens, a counter action by victims using sabotage and frequent agitations, protests, resentments, conflicts and sometimes anarchy. Such conditions lead to vicious circles where criminals are emboldened by lack of justice to becoming impudent and engaging in more crimes. Discontentment gradually sets in such societies and in the ensuing depressed situations, skilled citizens who cannot stand it all soon begin to emigrate.

\subsubsection{Problem Tree Analysis for Weak Institutions}

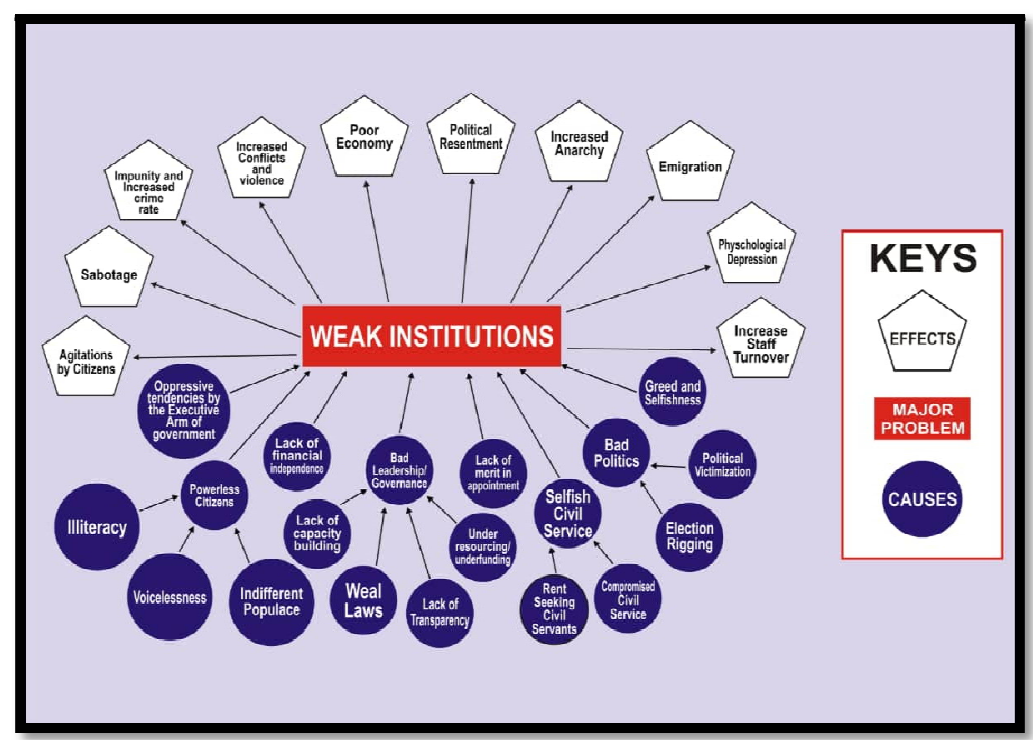

Figure 4: Showing the Problem Tree Analysis of Weal Institutions Source: Conceptualised by Authors (2020)

With regards to weak institutions, some of the key causes why institutions are weak include oppressive dictatorial leaders, who also ensure that institutions depend on them for all resources including finance, the quality of the political leaders and those leading the institutions, which is related to the engagement of incompetent institutional leaders who are subservient to the government officials and people who are compromised seeking personal favours rather than doing the work for which they have been employed.

Both good leadership and strong institutions are important for rapid sustainable advancement. However, wherever controls and rule of law are found to be weak, no matter the integrity of the leadership, corruption will not only persist it will flourish. Building functional and effective institutions are more important to sustainably fight corruption than to have just a strong and effective leader with high integrity. We must not only think of today because in the long run when the strong leader leaves office, corruption will re-emerge with greater force since there will not be strong institutions to check impunity. Let us also not forget that strong institutions are likely to ensure the emergence of good leadership.

The problem is that most dictators prefer weak institutions so that their actions are not questioned, and they become not accountable to anyone. Institutions are many but some key national bodies that should be given some attention are as follows: Press, Labour Unions, Civil societies, Educational bodies, Judiciary, Legislature, Human Rights Institutions, Electoral Umpires and Monitors, Law enforcement, etc. The magnitude of this problem in terms of availability of suitable human rights institutions in many nations is captured in the UN report 2019, which stated that only $39 \%$ of nations had national human rights institutions compliant with international standards.

Figures 2, 3 and 4 show the consequences of conflicts and injustice are similar to those that happen when the institutions of a nation are weak. This problem tree analyses have shown the good reasoning by the SDG formulators in putting these three arms together to form the backbone of SDG16.

\section{Conclusion and Recommendation}

It is evident that the promotion of peace, justice and strong institution plays key roles towards sustainable society, either directly or providing opportunities to fulfilling other SDGs. By implication, good leadership, independent and vibrant institutions and continuous capacity building play critical roles in the achievement of the SDGs and especially that of SDG16. Enforcement of 'Rule of Law', building strong institutions and encouraging conflict management capacity building reduce the frequent occurrence of violent conflicts and wars. These pursuits are essential if we want real sustainable development in the world that is stable and continuously improving. It is not only economic corruption that hinders sustainable peace and development, political corruption is equally a major factor. Political corruption includes vices like lopsided appointments, lack of meritocracy in the administration, election rigging, and victimization of real and perceived political enemies among many others (Figure 2). Conflicts can be minor disagreements, it can be violence within a locality, it can be between nations and it can equally involve the use of weapons of mass destruction (nuclear, biological, chemical and cyber). For effective implementation of SDG16, conflicts must be properly managed especially at the international levels. 
Some of the key causes of injustice are oppressive tendencies by leaders, weakened judiciary, corruption, jungle justice, bad politics and actions of greedy and selfish people. The entire shortcoming above has several deleterious consequences among which are arbitrary arrest of innocent citizens, a counter action by victims using sabotage and frequent agitations, protests, resentments, conflicts and sometimes anarchy.

With regards to weak institutions, some of the key causes why institutions are weak include oppressive leaders, who ensure that institutions depend on them for all resources including finance, engagement of incompetent institutional leaders who are subservient to the government officials or the executive arm of government preferring sycophantic institutional leaders that are seeking personal favours rather than doing the work for which they have been engaged.

As can be seen from the three problem tree analyses, the consequences of failed peace, injustice and weak institutions are often similar and their causes and effects are interwoven. The instruments used to execute major conflicts are often applied without any regard to fair-play and the protection of the innocent, without empathy and with the savagery philosophy that 'might is right 'where the winner of the conflict hopes to usurp the inheritance and assets of the vanquished. Equally, injustice often leads to violent conflicts where institutions cannot make leadership or the citizens to be accountable and responsible. Finally, a weakened institutional system will be a breeding ground for injustice to thrive and such situations sometimes result in violent reprisal attacks or protests for survival by the victims.

With this we recommend as follows:

- A constitutional review that makes key national institutions independent, having no financial control from the executive arm and engagements or sacking of the heads (institutional leaders) should not be made by only the executive arm of government but to have the Legislative arm playing equal or more roles in the process.

- In building peaceful society; institutions must constantly evaluate their performancesby independent auditors annually and same should be publish in terms of their level of independence from government controls and performance in terms of actual as against targets set.

\section{References}

i. Bignami, F., \& Zaring, D. (2016). Comparative Law and Regulation. Understanding the Global Regulatory Process, 353-382. https://doi.org/10.4337/9781782545613

ii. Einstein, A. (1968). Einstein on Peace, New York: Schocken

iii. Eriksen, E., O. (2016) Three Conceptions of Global Political Justice. GLOBUS Research Paper 1/2016. Available at SSRN: https://ssrn.com/abstract=2878745 or http://dx.doi.org/10.2139/ssrn.2878745

iv. Etymonline. (2017.). peace / Search Online Etymology Dictionary. Online Etymology Dictionary. Retrieved May 4, 2020, from https://www.etymonline.com/search?q=peace

v. Flores-Macías, G. A., \& Zarkin, J. (2019). The Militarization of Law Enforcement: Evidence from Latin America. Perspectives on Politics, 1-20. https://doi.org/10.1017/s1537592719003906

vi. Gupta1, J \&Vegelin, C. (2016). Sustainable development goals and inclusive development, Int Environ Agreements DOI 10.1007/s10784-016-9323-z, pp 1-16

vii. GPI (2017), executive summary, the Global Peace Index (GPI)-2017, Retrieved from http://visionofhumanity.org/app/uploads/2017/06/GPI17-Report.pdf

viii. Hayek, F., A. (1976). Law, legislation and liberty: a new statement of the liberal principles of justice and political economy. Routledge \& Kegan Paul.p. 78. ISBN 978-0-7100-8403-3. OCLC 769281087.

ix. Johnson, J., W. (2016). 'Equal Before the Law: How Iowa Led Americans to Marriage Equality.' The Annals of Iowa 75, 98-100. Available at: https://doi.org/10.17077/0003-4827.12276 Hosted by Iowa Research Online

X. Kapstein, E., B. (2006). Economic justice in an unfair world: Toward a level playing field, Princeton, NJ: Princeton University Press.

xi. IEP. (2016). what is positive peace? Positive Peace Report 2016, Retrieved from http://visionofhumanity.org/app/uploads/2017/02/Positive-Peace-Report-2016.pdf

xii. Lawrence, A., W. (2018). Some Governance and Peaceful Coexistence Issues for Sustainable Advancement: A Nigerian Perspective (2ndEdition), T\&D Press Ltd.

https://www.amazon.co.uk/Governance-Peaceful-Coexistence-Sustainable-Advancementebook/dp/B079HJBWX8/ref=sr_1_1?s=books\&ie=UTF8\&qid=1527510031\&sr=1-

$1 \&$ keywords=some+governance+and+peaceful+coexistence+issues7.

xiii. Lawrence, A. W, \& Lawrence, D., O. (2019). Conflict Escalation Processes and the Importance of Win/Win Conflict Resolution Outcome. The International Journal of Business \& Managements 7(9). Doi No.: 10.24940.

xiv. Lawrence, A. W., Ihebuzor, N and Lawrence D. O. (2020).Macro-Level Studies of Direct and Indirect Relationships between SDG 4 and the 16 SDGs Modern EconomyVol.11 No.6, June 24, 2020 D0I: 10.4236/me.2020.116085

xv. Long. S. L., \& Ponce. A., (2019) World Justice Project, measuring the justice gap - a people centred assessment of unmet justice needs around the world, Washington, World Justice Programme

xvi. Mill, J., S. (1991) Utilitarianism in On Liberty and Other Essays ed. John Gray. Oxford: Oxford University Press, Chapter 5.

xvii. Norwegian Parliamentary White Paper No. 17 (2001-2002), Societal Safety: The Road to a Less Vulnerable Society (own translation from Norwegian), Oslo

xviii. Olsen, O. E., Kruke, B. I., \&Hovden, J. (2007). Societal Safety: Concept, Borders and Dilemmas. Journal of Contingencies and Crisis Management, 15(2), 69-79. https://doi.org/10.1111/j.1468-5973.2007.00509.x 
xix. Ornstein, A. C. (2017). 'Social Justice: History, Purpose and Meaning'. Society. 54 (6): 541-548. doi:10.1007/s12115017-0188-8. ISSN 1936-4725.

xx. Reardon, B. A. (1988.), Comprehensive Peace Education. New York: Teachers College Press

xxi. Richmond, O., P. (2016). Peace: A Very Short Introduction. Scientific Information System, 9, $303-307$. https://doi.org/10.1093/actrade/9780199656004.001.0001

xxii. Rubinstein, D. (1988). 'The Concept of Justice in Sociology'. Theory and Society. 17 (4): 527-550. JSTOR 657654.

xxiii. Rawl, J. (1999). A Theory of Justice (revised edn, Oxford: Oxford University Press), p. 3

xxiv. Bali-Swain, R. \& Yang-Wallentin, F. (2020). Achieving sustainable development goals: predicaments and strategies, International Journal of Sustainable Development \& World Ecology, 27:2, 96-106, D0I: 10.1080/13504509.2019.1692316

xxv. Rocha, C. (2009) Promoting Economic Justice in a Global Context: International Comparisons of Policies That Support Economic Justice, Journal of Community Practice, 17:1-2, 31-49, DOI: 10.1080/10705420902856217

xxvi. Quarantelli, E. L. (2000), 'Disaster Planning, Emergency Management and Civil Protection: The Historical Development of Organized Efforts to Plan for and to Respond to Disasters' (preliminary paper 301), Disaster Research Center, University of Delaware, Delaware.

xxvii. Trostle, T. (1992), Personal correspondence, New York

xxviii. Wiedeman, C., R. (2002). Teacher Preparation, Social Justice, Equity: A Review of the Literature, Equity \& Excellence in Education, 35:3, 200-211, DOI: 10.1080/713845323

xxix. United Nations Department of Economic and Social Affairs (UNDESA) and the International Law Development Organization (IDLO) (2019) 'Peaceful, Just and Inclusive Societies: SDG 16 implementation and the path toward leaving no one behind' Background paper presented at conference by UNDESA, IDLO co-organized by the with the Government of Italy - Rome, Italy from 27-29 May, 2019.

xxx. United Nations Report. (2020). Available athttps://www.un.org/sustainabledevelopment/peace-justice/ 